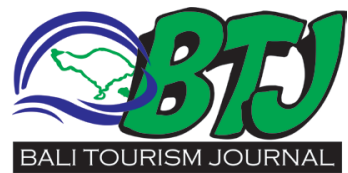

\section{Local Tourist favored Tanah Lot as a place to visit after COVID-19 lockdown}

\author{
Ida Ayu Agung Adnyawati ${ }^{1}$
}

\title{
ABSTRACT
}

Tabanan Regent Ni Putu Eka Wiryastuti reopened five tourist attractions in Tabanan district closed since 22 March 2020 due to the Covid-19 pandemic. Those Tourist attractions were Tanah Lot, Ulundanu Temple, Eka Karya Botanical Garden Bedugul, The Blooms Garden Baturiti, and Jatiluwih, Penebel. She explained the decision was urgently needed to resurrect economic activity in Tabanan district in the new normal phase. ' Since the reopening day, domestic tourists flooded Tanah Lot, Tabanan. The number of visits had skyrocketed, starting from 20 July to 22 August 2020. As one of Bali's leading preferable tourist destinations, Tanah lot offers majestic landscapes and historical value that should not be missed. Established in the $16^{\text {th }}$ century, Tanah Lot is a temple for lord of the sea, after a priest named Dang Hyang nirartha received revelation on a vast reef at the beraban village coast. Later, Tanah lot is considered a holy site and a favorite landmark for tourism. COVID-19 outbreak forced the local Government to close most public places on the island. On 20 July 2020, Tabanan regent decided to reopen five out of many tourism objects in its area, including the coastal landmark. Since reopening, its number of visits spiked rapidly, over twenty thousand visits in less than a month. Despite its huge demand, it did not significantly impact the economic atmosphere around the area. The management explained that the hawkers believed tourist visits were relatively low compared to before the pandemic. They argued the visitor purchasing power might also go down. The other reasons were that some stall owners terminated their contracts, and some preferred to sell from their homes.

Keyword: Tanah lot, Temple, COVID-19

Cite This Article: Adnyawati, I.A.A. Local Tourist favored Tanah Lot as a place to visit after COVID-19 lockdown. Bali Tourism Journal (BTJ) 2020, 4(2): 27-30. D0I : 10.36675/btj.v4i2.44

${ }^{1}$ Segara The Seaside bar and Restaurant Bali aadnyawati@gmail.com

\section{Editor:}

Ida Bagus Ngurah Tri Pramana
Received : 2020-04-30 Accepted : 2020-06-25 Published: 2020-07-02

\section{BACKGROUND}

Tabanan Regent Ni Putu Eka Wiryastuti reopened five tourist attractions in Tabanan district closed since 22 March 2020 due to the Covid-19 pandemic. Those Tourist attractions were Tanah Lot, Ulundanu Temple, Eka Karya Botanical Garden Bedugul, The Blooms Garden Baturiti, and Jatiluwih, Penebel. She explained the decision was urgently needed to resurrect economic activity in Tabanan district in the new normal phase. ${ }^{1}$ Since the reopening day, domestic tourists flooded Tanah Lot, Tabanan. The number of visits had skyrocketed, starting from 20 July to 22 August 2020. According to the Tanah Lot management office, as cited by Kompas, the report showed 21,229 domestic tourist visits and 656 foreigners' visits in total. ${ }^{2} \mathrm{No}$ wonder, Tanah lot has been considered the most favorite destination for tourists over the years due to its iconic offshore temple, with a southern ocean landscape.

\section{A TEMPLE FOR THE OCEAN LORD}

Situated approximately 20 kilometers North West of Denpasar, on the coast of Beraban village, Tabanan regency. Tanah Lot is a Hindu temple that rests on top of a vast offshore rock. Its existence is strongly related to an influential priest named Dang Hyang Nirartha. Nirartha's pilgrimage to Bali Island was in the $15^{\text {th }}$ century, which was ruled by King Dalem Waturenggong. The king was supported Dang Hyang Nirartha's mission to spread Hinduism teaching, especially in remote villages throughout the island. According to the history of Tanah Lot, Nirartha visited the Tanah lot area after he saw an illuminating light from the southern coast. Driven by curiosity, he sought the light source and arrived on the southern coast near a small fishermen village called Beraban. Nirartha was captivated by the coastal landscape. Suddenly, His intuition urged him to build a temple above a beak-shaped rock as an altar for Baruna, the lord of the ocean. However, Beraban village chief, Bendesa Beraban Sakti, was displeased with the priest's activity in his area.

Bendesa Beraban Sakti sought to banish Nirartha by any means necessary. The legend told that the priest, with his spiritual power, moved the rock to the middle of the water. Hence the name is Tanah Lot. Tanah Lot means a rock in the middle of the ocean. To protect the temple, Dang Hyang nirartha also turned his sash into a coral reef snake. Hitherto, the snake can be seen and has been protected by the locals. Beraban chief acknowledged the priest's 


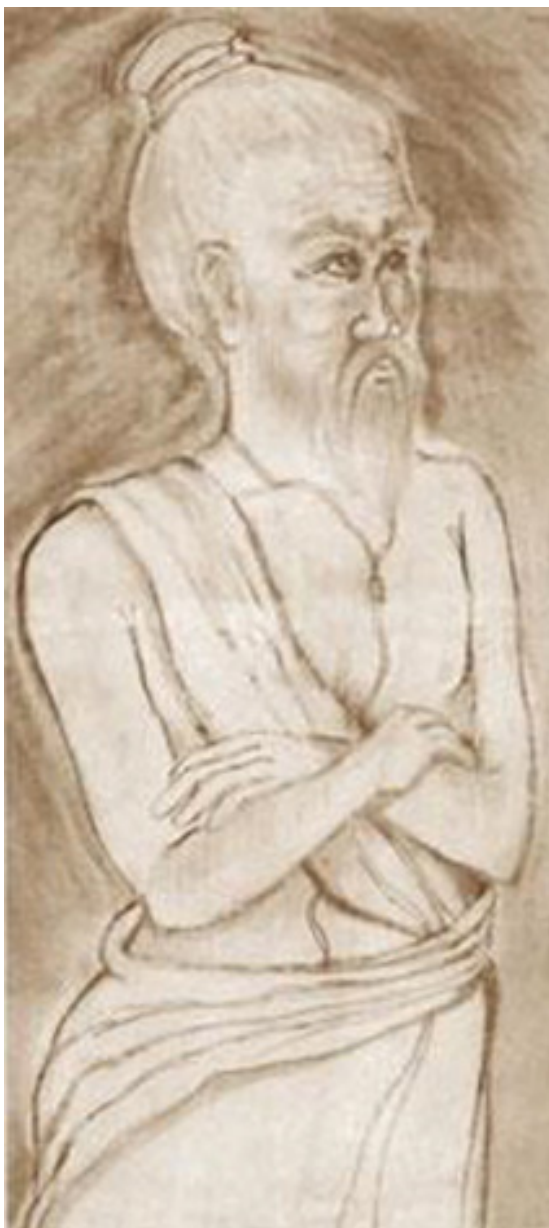

Figure 1. Illustration of Dang Hyang Nirartha ${ }^{3}$

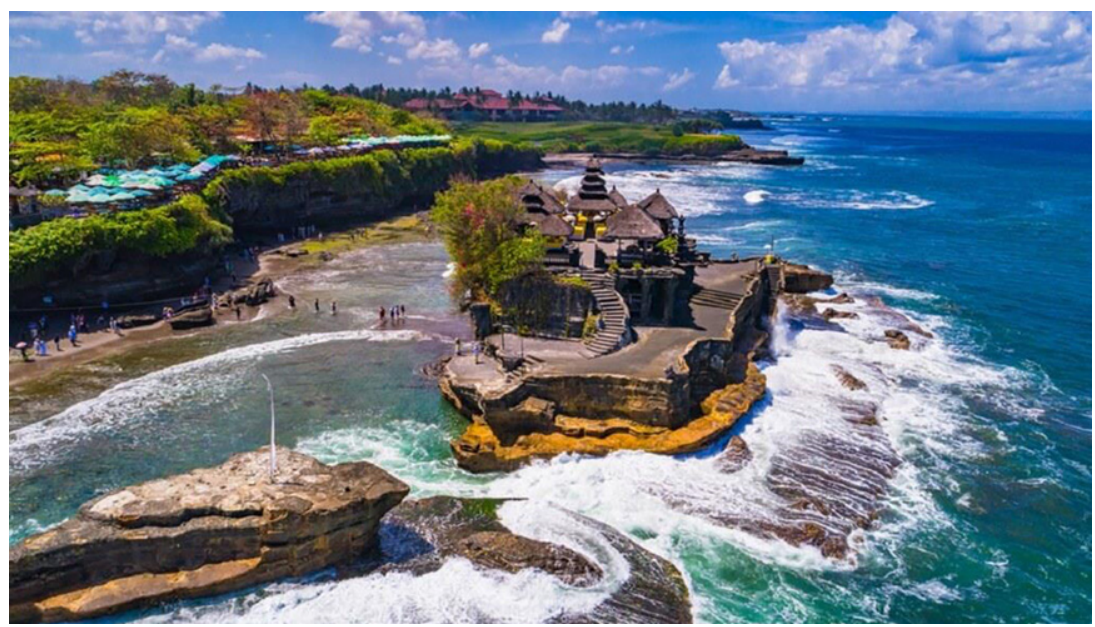

Figure 2. Aerial view of Tanah $\operatorname{Lot}^{4}$

superiority and willingness to accept him in the village.

Furthermore, Bendesa Beraban Sakti, along with all residents, converted to Hindu since then. As a token of gratitude, Dang Hyang Nirartha handed a Keris to Bendesa Beraban Sakti. The blade imbued with the power to ward off plagues and diseases, which lingered on Beraban village before the priest's arrival. The Keris is now being kept at Puri Kediri, Tabanan. A religious ceremony is held at Tanah Lot Temple every six months as a symbol to maintain peace and prosperity in Beraban village.

Tanah Lot temple layout is distinctive to other temples on Bali due to its location above an offshore coral rock. The rock irregular shape, as well as its size, make the temple is relatively small. On high tide, the temple can be reached by boat. However, on low tide, it could be extended by walk. Since the Tanah lot temple is a sacred place for Hindus in Bali, the visitor can only do their activity around the area. Only prayer is authorized to enter the main temple and must wear prayer clothes.

\section{TANAH LOT AS TOURISM OBJECT}

The Tanah lot area consists of several temples, shrines, an open stage, tourists' rest area with restaurants and art shops, wide parking lot, and a memorial pillar. The heroic monument within the Tanah lot area is called the tri antaka monument. The pillar was built to remember three war heroes: I Gusti Ketut Kereg, I Wayan Kamias, and I Nyoman Regug, who fought the NICA (Netherlands Indies Civil Administration) 1946.

To reach the iconic offshore temple, tourists need to take a ten-minute walk from parking lot through the tourists' area to find the coast. The visitor commonly prefers to capture their moment at Tanah Lot from famous spots around 'enjung galuh' walking track or 'Sunset Terrace' to obtain perfect shots. Enjung Galuh is the name of a shrine dedicated to praising Dewi Sri, Goddess of prosperity. The visitor may take a picture from the walking track, but not to enter the temple. Around 100 meters to the west from enjung galuh, there is Batu Bolong temple, then Batu Mejan temple.

Meanwhile, Sunset Terrace is a restaurant located in the northern area of the main temple. Unlike enjung galuh, the spot is designed to fulfill tourist expectations, with the offshore temple view, where guests may enjoy their meal while beholding the southern coast skyline. When exploring the area, the visitor may find Penataran Temple in the north of the offshore temple. Just a few walks to the western side of Penataran Temple, there is Penyawang Temple, then Jro Kandang Temple, a temple to ask for protection from animals and plant diseases. $^{6}$

Although the nearby shrines offer compelling spiritual experiences, most visitors are curious about the mild-nature coral reef snakes that reside under the boulder near the main temple. The 


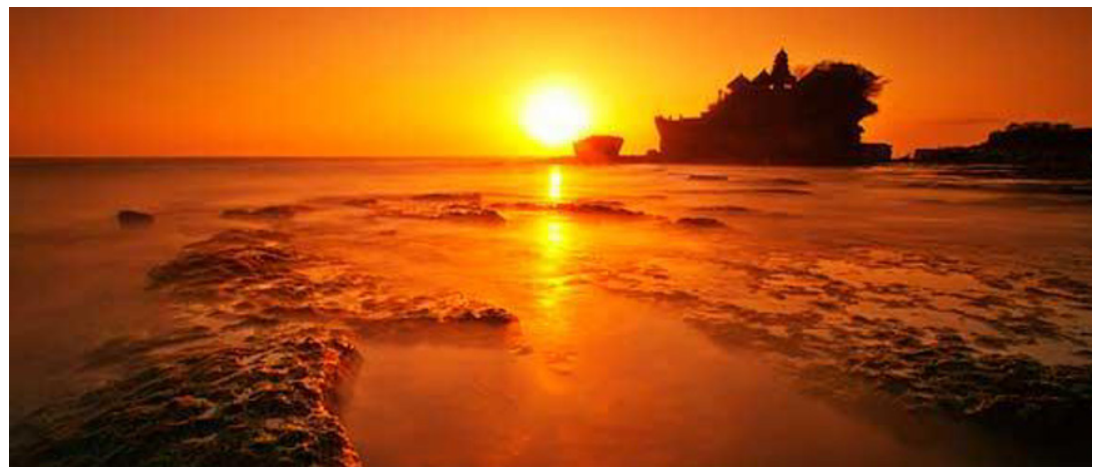

Figure 3. Iconic Sunset of Tanah $\operatorname{lot}^{5}$

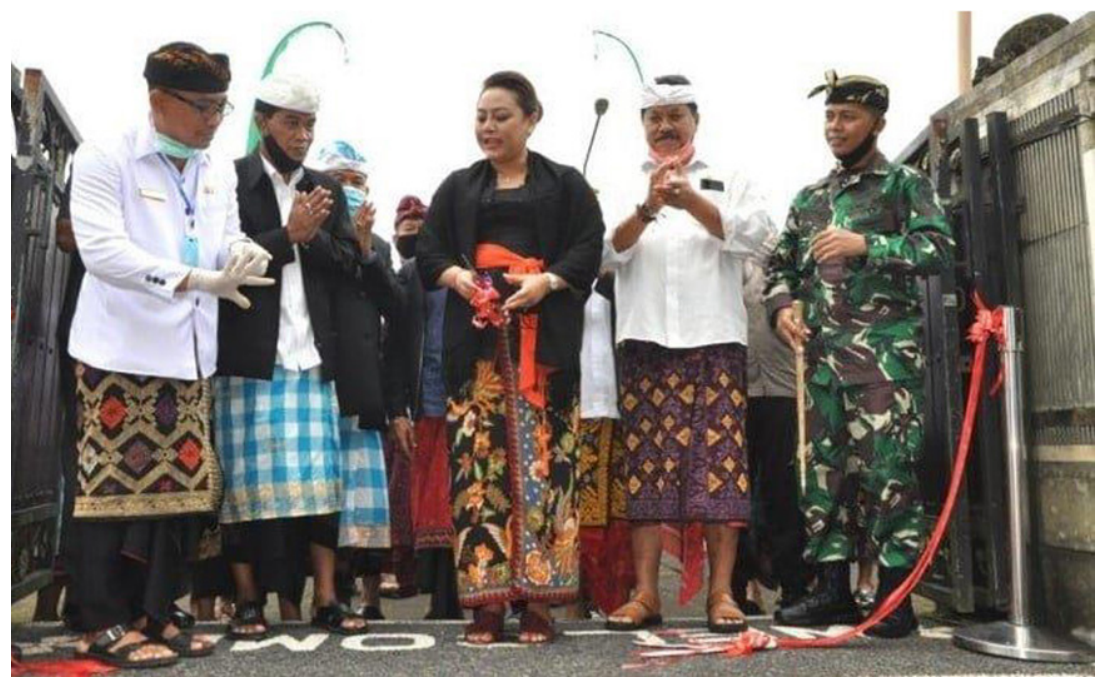

Figure 4. Tabanan Regent, Eka Wiryastuti (middle) when reopened five tourism objects in Tabanan regency, including Tanah Lot. ${ }^{10}$

snakes are protected by some 'pecalang' to ensure the visitor's safety and protect the serpent from irresponsible tourists. Despite its friendly nature, it is compulsory to keep hands out from the animal unless the officer allows them to do so.

Arguably, Tanah Lot's unique selling point lies in the landscape of Tanah lot temple and enjung galuh temple, high ocean tide, and sunset. Should those three elements meet together, nature would provide a breathtaking orange twilight sky. The dim light would create backlight to the temples. Combined with high tide, it would make the temple seems floating in the middle of the ocean. All the elements would present the beholder, a dark silhouette landscape that resembles a substantial black ship sailing toward the horizon. ${ }^{7,8}$

\section{STRATEGIC PLAN TO SAVE THE ECONOMY}

Mcintoch, Goeldner, and Ritchie (1995) proposed four key points that encourage tourists to visit tourism objects: pleasure, local culture interest, new experiences, and Community prestige. ${ }^{9}$ Both domestic and foreign visitors dream of spending their time to behold the exotic sunset of Tanah Lot. Although Tanah Lot is a holy site for Balinese, a study states that most tourists' motivation in visiting Tanah Lot was to know more about the culture and the local way of life. The impact of Covid-19 on community socio-economy reflected on both stagnation and negative economic growth. The effect is not only happening in Tabanan but also in all parts of the world. It is understandable why Tabanan Regent decided to reopen Tanah lot since tourist positively demands it.

According to Tabanan regent, Eka wiryastuti, the local Government avoids recklessly open all destinations due to health protocols' readiness. Therefore, they only selected five sites as a pilot project. However, she admitted that an evaluation would be regularly conducted to minimize the possibilities of health protocol violations. ${ }^{1}$

Operation Manager of Tanah lot, I Ketut Toya adnyana, revealed Domestic tourist visits in Tanah Lot had reached 21,229 domestic visits and 656 foreigners' visits since it opened on 20 July 2020. He explained that local tourists dominated the visit, Followed by domestic tourists from Jakarta, Malang, and Mojokerto. Furthermore, foreign tourist visits were dominated by Australian and European expatriates. Tourists who visit are mandatory to wear a mask, wash their hands, and have their body temperature checked. ${ }^{2}$ Besides, Tanah Lot management did not make any change to the ticket's rate. ${ }^{11}$ Meanwhile, Head of the Tanah Lot Market Division, Made Adhi Susila, revealed that only 2 percent of many stalls decided to open after the Tanah lot reopening. The hawkers argued that the number of tourist visits is relatively low compare to the pre-COVID 19 pandemics, including the visitor's purchasing power. Data from the public relations of Tanah Lot, the average tourist visit per day is only 500-600 people per day, while on Saturdays and Sundays, the figure is around 1,000 visits. Adhi admitted that some stall owners had terminated their contracts, and some prefer to sell from their home. ${ }^{12}$

\section{CONCLUSION}

Tabanan regent declared reopening their five most favorite land wonders, including the Tanah lot. As one of Bali's leading preferable tourist destinations, Tanah lot offers majestic landscapes and historical value that should not be missed. Established in the $16^{\text {th }}$ century, Tanah Lot is a temple for lord of the sea, after a priest named Dang Hyang nirartha received revelation on a vast reef at the beraban 
village coast. Later, Tanah lot is considered a holy site and a favorite landmark for tourism.

COVID 19 outbreak forced the local Government to close most public places on the island. On 20 July 2020, Tabanan regent decided to reopen five out of many tourism objects in its area, including the coastal landmark. Since reopening, its number of visits spiked rapidly, over twenty thousand visits in less than a month. Despite its huge demand, it did not significantly impact the economic atmosphere around the area. The management explained that the hawkers believed tourist visits were relatively low compared to before the pandemic. They argued the visitor purchasing power might also go down. The other reasons were that some stall owners terminated their contracts, and some preferred to sell from their homes.

\section{REFERENCES:}

1. NF Yusuf; B Suryanto. ' 5 Tempat Wisata di Tabanan Bali Buka Kembali, Salah Satunya Tanah Lot. Kompas[dot] com. 2020. Available at URL: https://travel.kompas.com/ $\mathrm{read} / 2020 / 07 / 20 / 193006127 / 5$-tempat-wisata-di-tabananbali-buka-k Kembali-salah-satunya-tanah-lot.

2. KD Cahya. 'Wisata ke Tanah Lot Diminati, Ada 21.229 Kunjungan Turis Domestik Sejak Dibuka'. Kompas[dot] com. 2020. Available at URL: https://travel.kompas. com/read/2020/08/24/211500327/wisata-ke-tanah-lotdiminati-ada-21229-kunjungan-turis-domestik-sejakdibuka.

3. Illustration from Suryadinata Putra 'Dang Hyang Nirartha/ Dang Hyang Dwijendra/Pedanda Sakti Wawu Rawuh/ Tuan Semeru'. Ilmuhindu blog. 2011. Available at URL: http://ilmuhindu.blogspot.com/2011/09/dang-hyangnirarthadang-hyang.html
4. Image from Airpaz blog 'Keindahan dan Eksotisnya Pura Tanah Lot Bali Indonesia'. Airpaz blog. 2017. Available at URL: https://blog.airpaz.com/id/keindahan-daneksotisnya-pura-tanah-lot-bali-indonesia/

5. Image by W Suadnyana; H Kessell 'Keindahan Sunset Tanah Lot Tabanan - Pemandangan Favorit Wisatawan Saat Liburan'. Rentalmobilbali[dot]net. 2020. Available at URL: https://www.rentalmobilbali.net/keindahan-sunsettanah-lot/

6. Official website of DTW Tanah Lot. 2020. Available at URL: https://tanahlot.id/

7. KUSUMA, I. Gusti Agung Riza Dwi; SURYASIH, Ida Ayu. Aktivitas Wisata Spiritual dan Motivasi Berwisata di Daya Tarik Wisata Tanah Lot Kabupaten Tabanan. Jurnal Destinasi Pariwisata ISSN, 2016, 2338: 8811.

8. ARIFANO, Muh Mazda. Tanah Lot Sebagai Daya Tarik Wisata Di Bali. 2013.

9. MCINTOSH, Robert Woodrow, et al. Tourism: principles, practices, philosophies. John Wiley and Sons, 1995.

10. Image from Berita Bali Online 'Bupati Eka Buka 5 Destinasi Wisata di Kabupaten Tabanan'. Beritabalionline[dot] com. 2020. Available at URL: https://beritabalionline. com/2020/07/20/bupati-eka-buka-5-destinasi-wisata-dikabupaten-tabanan/

11. Anonymous. Tanah Lot Mulai Ramai, Belum Rencanakan Ada Diskon. Bali express. 2020. Available at URL: https:// baliexpress.jawapos.com/read/2020/08/21/209901/tanahlot-mulai-ramai-belum-r Rencana-ada-diskon

12. Puspawati. Kunjungan Masih Minim, kios dan los Di DTW Tanah lot banyak Tutup. Bali Post. 2020. Available at URL: https://www.balipost.com/news/2020/08/27/144069/ Kunjungan-Masih-Minim,Kios-dan...html

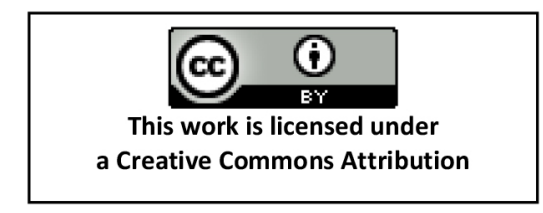

